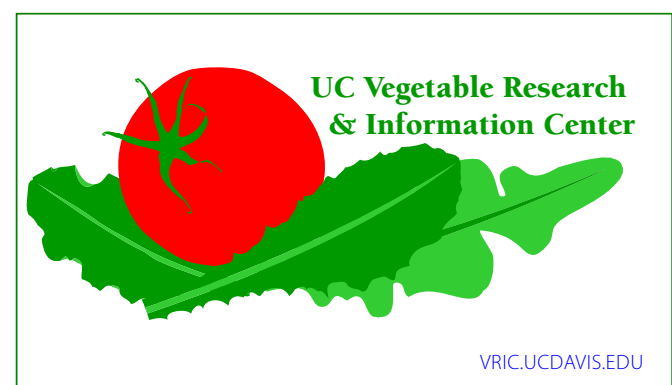

Vegetable Production Series

\section{CARROT PRODUCTION IN CALIFORNIA}

JOE NUÑEZ, University of California Cooperative Extension Farm Advisor, Kern County; TIM HARTZ, University of California Cooperative Extension Vegetable Crops Specialist, University of California, Davis; TREVOR SUSLOW, University of California Cooperative Extension Postharvest Specialist, University of California, Davis; MILT MCGIFFEN, University of California Cooperative Extension Plant Physiologist, University of California, Davis; and ERIC T. NATWICK, University of California Cooperative Extension, Imperial County

\section{PRODUCTION AREAS AND SEASONS}

California has four main production areas for carrots (Daucus carota): the southern San Joaquin Valley and the Cuyama Valley (Kern and Santa Barbara Counties); the southern desert (Imperial and Riverside Counties); the high desert (Los Angeles County); and the central coast (Monterey County).

Carrots are grown year-round in California. In the southern San Joaquin and Cuyama Valleys, carrots are planted from December to March for harvest from May to July and from July to September for harvest from November to February. In the southern desert, they are planted from August to February for harvest from December to June. In the high desert they are planted from April to July for harvest from August to December. On the central coast, they are planted from December to August for harvest from April to January.

FRESH MARKET CARROT ACREAGE AND VALUE

\begin{tabular}{|c|c|c|c|}
\hline Year & Acreage & $\begin{array}{c}\text { Average yield } \\
\text { (ton/acre) }\end{array}$ & $\begin{array}{c}\text { Gross value/ } \\
\text { acre }\end{array}$ \\
\hline 2003 & 68,000 & 15.00 & $\$ 6,120$ \\
\hline 2004 & 66,500 & 15.25 & $\$ 6,558$ \\
\hline 2005 & 67,500 & 15.50 & $\$ 6,677$ \\
\hline 2006 & 69,500 & 15.25 & $\$ 6,389$ \\
\hline
\end{tabular}

Source: National Agriculture Statistics Service 2007 (United States Department of Agriculture, 2007).

PROCESSING CARROT ACREAGE AND VALUE

\begin{tabular}{|c|c|c|c|}
\hline Year & Acreage & $\begin{array}{c}\text { Average yield } \\
\text { (ton/acre) }\end{array}$ & $\begin{array}{c}\text { Gross value/ } \\
\text { acre }\end{array}$ \\
\hline 2003 & 3,500 & 32.3 & $\$ 3,230$ \\
\hline 2004 & 4,300 & 32.0 & $\$ 3,552$ \\
\hline 2005 & 4,100 & 35.0 & $\$ 2,870$ \\
\hline 2006 & 4,500 & 33.0 & $\$ 4,125$ \\
\hline
\end{tabular}

Source: National Agricultural Statistics Service 2007 (United States Department of Agriculture, 2007).

\section{CLIMATE REQUIREMENTS}

Carrots, a cool-season crop, will tolerate warm temperatures early in the growing season. Roots attain optimal color when the air temperature is $60^{\circ}$ to $70^{\circ} \mathrm{F}$ $\left(18^{\circ}\right.$ to $\left.21^{\circ} \mathrm{C}\right)$. Root color can deepen rapidly when temperatures are within this range 3 weeks before harvest. Above $86^{\circ} \mathrm{F}\left(30^{\circ} \mathrm{C}\right)$, the growth of foliage is reduced and strong flavors develop in the roots, reducing their market quality. Below $50^{\circ} \mathrm{F}\left(10^{\circ} \mathrm{C}\right)$, carrot roots and foliage grow slowly. Carrots may tolerate some frost.

\section{VARIETIES AND PLANTING TECHNIQUES}

Consumer demand for uniform roots of deep orange color has led to extensive use of Imperator-type hybrids. Varieties for the cut and peel market include Sugarsnax, Topcut, Primecut, Trinity, Imperial Cut, and Tastypeel. Cello varieties commonly used include Apache, Navajo, Maverick and Choctaw. Some of the major producers in California also use their own proprietary varieties. Nantes-type varieties, commonly grown in Europe and in home gardens, are not normally grown commercially in California. There is a growing interest by producers in other colored carrots such as reds, yellows, and purple, and these are beginning to be grown on a larger scale.

Carrots are always direct seeded. Both raw and pelleted seed are used. Carrot seed vary from 175,000 to 400,000 per pound $(80,000$ to 180,000 per $\mathrm{kg}$ ) and are sown at the rate of 0.9 to 1.3 million seeds per acre ( 0.4 to 0.5 million per ha). Higher densities are used for plantings for the cut and peel market. Seed within a lot vary significantly in size, maturity, vigor and germination time; emergence often occurs over several days. Seed are most commonly sown in six or eight lines in beds 40 inches $(1 \mathrm{~m})$ wide with three or four rows on each bed shoulder. Seed are placed in a narrow groove and are lightly covered. 


\section{SOILS AND IRRIGATION}

The upper 30 inches $(75 \mathrm{~cm})$ of soil should be uniform and free of barriers to root growth. Although carrots are often grown on sandy soils, the ideal soil is silt loam, which provides the best combination of water-holding capacity and drainage. Heavy soils can encourage hairy, deformed roots. Carrots can be successfully produced in both acid and alkaline soils; California carrot fields typically range in $\mathrm{pH}$ from 5.5 to 8.0.

A uniform water supply is critical for good color and root formation. If significant wet-dry cycles occur, the roots will split. Excessive watering discourages good color formation and may encourage disease. Carrots are usually irrigated by solid-set sprinklers. In the Imperial Valley, carrots are germinated using solid-set sprinklers, then switched to furrow irrigation at the first cultivation. Some acreage has been converted to center pivot irrigation, but its use is still limited. Drip irrigation has been tested with carrots, but the results have been poor.

\section{FERTILIZATION}

Carrot is a deep-rooting crop, able to efficiently extract nitrogen $(\mathrm{N})$ from soil to a depth of several feet. Seasonal nitrogen application varies widely among growers and fields, ranging from as low as 100 pounds of nitrogen per acre $(110 \mathrm{~kg} / \mathrm{ha})$ to over 250 pounds per acre $(280 \mathrm{~kg} / \mathrm{ha})$. University research has shown that seasonal nitrogen rates greater than 150 pounds of nitrogen per acre $(170 \mathrm{~kg} / \mathrm{ha})$ are seldom necessary to maximize root yield, and that excessive nitrogen application increases root cracking during harvest and handling. A small amount of nitrogen is typically applied preplant with phosphorus $(\mathrm{P})$ fertilizer, with the majority of nitrogen applied either as a sidedressing or through sprinkler irrigation.

Phosphorus fertilization should be done based on soil test phosphorus level. Fields with soil phosphorus greater than $30 \mathrm{ppm}$ (by the bicarbonate extraction method, suitable for neutral to alkaline soils), or greater than 70 ppm (by the Bray extraction method, suitable for acid soils) require minimal phosphorus fertilization. Soils with very low soil phosphorus levels may require as much as 250 pounds of $\mathrm{P}_{2} \mathrm{O}_{5}$ per acre $(280 \mathrm{~kg} / \mathrm{ha})$. Likewise, potassium (K) fertilization should be done on the basis of a soil test. Fields with exchangeable potassium greater than $100 \mathrm{ppm}$ are likely to respond positively to potassium fertilization, while fields with greater than 200 ppm exchangeable potassium should not require potassium fertilization. Application rates as high as 200 pounds of $\mathrm{K}_{2} \mathrm{O}$ per acre $(225 \mathrm{~kg} / \mathrm{ha})$ may be justified in sandy soils with very low exchangeable potassium.

\section{ROOT FORKING, STUBBING, AND COLOR}

Damage to the growing root tip may cause the carrot root to fork or stub, rendering it unmarketable. Forking or stubbing often occurs within a few weeks after the seed germinates. Many diseases can cause forking. Poor soil structure, improper irrigation management, or hard freezes can also cause forking or stubbing. To help prevent forking and stubbing, prepare the soil well so that it has good tilth and drainage and avoid over- or under-watering young carrots.

As the carrot root matures, carotene accumulates, causing the root to change from yellow-white to yellow and then orange. Although varieties differ in their potential for orange color, soil fertility, temperature, and water content have the main effects on root color. The health of the leaves plays a minor role in root color unless the tops are severely stressed.

\section{INTEGRATED PEST MANAGEMENT}

Integrated pest management (IPM) information is continually being developed for carrots. Cultural control methods such as mechanical cultivation, field sanitation, and good drainage and irrigation management are important components of IPM that help minimize chemical controls. Herbicides, insecticides, nematicides, and fungicides should always be used in compliance with label instructions. For detailed information about IMP for carrots, see the UC IPM Pest Management Guidelines for Carrots Web site, http:/ / www.ipm.ucdavis.edu/PMG/selectnewpest. carrots.html. Herbicides, insecticides, and fungicides should always be used in compliance with label instructions.

\section{Weed Management}

Many weeds, including summer and winter annuals and perennials, are pests of carrots. Nutsedges, both yellow (Cyperus esculentus) and purple (C. rotundus), are the worst weed pests in carrots. Postemergence herbicides control yellow nutsedge, but no herbicide is registered for purple nutsedge control in carrots. Cultivation and preplant chemical treatments offer some control of nutsedges, and fallow summer treatments can also be effective. Nutsedges do not compete with fall-planted carrots because nutsedge growth slows and eventually ceases as temperatures cool and as carrots provide more shade. Preemergence or postemergence herbicides are available for control of grass, cereal, and broadleaved weeds; chemicals applied to control nematodes may also control weeds. Consult your local UCCE Pest Control Farm Advisor for details. 


\section{Insect Identification and Control}

Crickets, grasshoppers, pale-striped flea beetle larvae and adults, cutworms, and saltmarsh caterpillars can be serious pests of carrots by feeding on seedlings. Remove weeds in or near fields and disk in plant residue from infested fields to help keep flea beetle populations low.

Saltmarsh caterpillars (Estigmene acrea) are a problem in carrot fields planted next to a cotton field that has been defoliated for harvest. Building trenches or other barriers at the border of the cotton field can stop the movement of these pests.

Aphids (various species) can be serious pests of carrots at all stages of development. Besides directly feeding on carrots, they also vector several viral diseases. Chemical control is usually not required for aphids because naturally occurring predators and parasites help keep their populations below economic threshold levels. Field sanitation helps reduce the aphid population. Carrots should not be planted near cotton or melons to reduce the movement of the cotton-melon aphid (Aphis gossypii) into carrot fields when these crops are harvested.

Dense populations of adult silverleaf whitefly (Bemisia argentifolii) may immigrate into late-August or September plantings of carrots in the low deserts of southern California and may damage seedlings. Whiteflies cause damage by removing plant sap. Additionally, moderate to high populations of whitefly nymphs can contaminate foliage with honeydew and sooty mold, reducing photosynthesis.

\section{Disease Identification and Management}

The fungi Pythium ultimum, P. irregulare, Rhizoctonia solani, and Macrophomina spp. can cause forking, stubbing, and dieback in carrots. Soil fumigation can reduce the amount of dieback in a field and can control several other pests as well. Powdery mildew, a fungal disease, can be a problem in areas with high humidity and warm temperatures. Symptoms of powdery mildew are white powdery growths on the upper surface of the leaves. Seedling damping-off can be the result of Pythium spp., Rhizoctonia solani, and other soilborne fungal pathogens. Seed treatments and soil fumigation to control nematodes and/or weeds can reduce damping-off pathogens.

Cavity spot can be a severe disease of carrots that can cause the loss of the entire crop. This disease is caused by the soilborne fungal pathogens Pythium violae and P. sulcatum. Small, brown, water-soaked lesions develop on the root surface and may enlarge and open into a dry, sunken lesion as the carrot matures. Cavity spot generally increases in fields with a previous history of carrot plantings. Alfalfa is also a host for $P$. violae, and carrots that follow alfalfa may show symptoms. Fungicide applied preplant and in two to three postplant applications reduces cavity spot.

Root rots of carrots can be caused by several plant pathogens. Cottony soft rot (Sclerotinia sclerotiorum), a problem in cool, moist conditions, is a cottony white mass of fungal growth around the base of the carrot. Large black sclerotia can be found in the fungal mass and on the carrot itself. It can be reduced by deep plowing before planting and by chemical treatments.

Southern blight (Sclerotium rolfsii) favors warm temperatures. It produces a low-lying dense mat of brown fungal growth on the soil surrounding the carrot, with brown sclerotia located throughout the fungal mat. It can be reduced by deep plowing before planting and rotating to nonhost crops such as small grains or corn.

Bacterial soft rot (Erwinia carotovora) can be recognized as a soft rot not associated with any fungal growth and accompanied by a foul odor. It occurs in waterlogged soils during warm temperatures. Preparing the soil to eliminate low spots, increasing drainage, and avoiding overwatering are control measures for all the soft rots.

Leaf blights are caused by several pathogens and can be difficult to identify in the field. Alternaria leaf blight (Alternaria dauci) can be very serious. Symptoms appear as dark-brown to black necrotic lesions along the margins of the leaves and on the petioles. Symptoms first appear on the older foliage and then on younger leaves if warm, moist conditions persist. Long-beaked, multicelled comidia can be seen with the aid of a microscope on the leaves and petioles of diseased plants. Under a microscope, carrot early blight (Cerocospora carotae) can be differentiated from Alternaria leaf blight by the very thin threadlike spores. C. carotae produces on the lesions.

Bacterial blight (Xanthomonas campestris) symptoms are slightly different from those of Alternaria leaf blight in that the lesions are not as dark and may be surrounded by a yellow halo. Bacterial oozing may also be seen on the lesions present on the leaves and petioles. The bacterial exudates are particularly visible on the flower stalks of plants that have bolted.

Alternaria leaf blight and bacterial blight are seedborne diseases that can be avoided by planting seed known to be disease free. Fungicides can be used for control of early blight and Alternaria blight. Copper fungicides work best for bacterial blight, although this disease is rarely a serious problem.

The main symptoms of black root rot (Alternaria radicina) are black lesions on the base of the petioles. The lesions may extend down into the root, causing the characteristic "black crown." Crop rotation may reduce the spores in the soil; the spores are known to survive in the soil for more than 5 years without 
a host. Plowing, to turn the spores under, has been shown to reduce the incidence of this disease in fields with a history of black root rot. Fungicides can also be used for control but must be directed at the canopy to protect the petioles and crown.

Two viruses affect carrots in California. Carrot motley dwarf is found in the cooler carrot-growing regions along the central coast. Infected plants appear stunted and have reddish tops. The disease is transmitted by aphids to newly planted fields from previously infected overwintering fields and can be controlled by avoiding planting near overwintering carrot fields. Carrot thin leaf is another aphid-vectored viral disease that can spread from infected volunteer carrots. Symptoms are the thin leaves that give the virus its name. Eliminating volunteer carrots reduces the chances of the virus spreading into newly planted fields.

\section{Nematodes}

The root-knot nematode (Meloidogyne spp.), the primary nematode pest of carrots, causes stubbing, forking, and galling of the roots. It is found in all carrotgrowing regions of California. Other nematode pests include the stubby root nematode (Trichodorus spp. and Paratrichodorus spp.) and the needle nematode (Longidorus africanus). Nematicides or soil fumigants are used to control nematodes. Soil fumigants applied by chemigation or injection into the soil may give other benefits such as weed and soilborne disease control. Crop rotation can also reduce these pests.

\section{HARVESTING AND HANDLING}

Commercially grown carrots are harvested using self-propelled multirow harvesters. Some machines can harvest more than 1,000 tons (907 t) of carrots per day (about 30 semi-truck loads). The 4-row machines dig two beds 42 inches $(105 \mathrm{~cm})$ wide per pass, lift the roots using a system of belts, shear off the tops, and deposit the roots into a waiting truck or trailer. The carrots are then hauled to a shed for washing, grading, sizing, and packing. In the Central Valley, carrots are hauled a short distance, usually to sheds in Bakersfield, whereas carrots grown in the desert may be hauled over 300 miles $(480 \mathrm{~km})$. The grower pays part of the freight to the shed. On average, 40 to 80 percent of all the carrots growing in the field are harvested and "packed out." Carrots that are damaged by the harvester or by insects or are diseased, deformed, or off-color are culled.

Carrots may be grown specifically for the cut and peel market, or culled carrots may be cut and peeled. Harvesting carrots for the minicarrot and cut and peel market is difficult because of the high density of roots. During harvesting, excess dirt may be picked up, increasing the tare hauled to the shed. Dirt is also expensive to remove and dispose of at the shed. For bunched carrots the beds are undercut and the carrots are hand-sorted in the field. The green tops are bound with a wire twist tie, and the bunches are loaded onto flatbed trucks and hauled to the shed for washing and packaging. Careful handling of carrots during and after harvest prevents bruising, shatter-cracks, and tip breaks and prolongs storage life.

\section{POSTHARVEST HANDLING}

Before storage, carrots are generally washed and hydrocooled in clean water with $100 \mathrm{ppm}$ chlorine at $\mathrm{pH} 6.5$ to 7.5 before being packed in plastic-lined bins. Research has shown, however, that if carrots are to be stored for an extended period, carrot quality is highest and postharvest losses lowest if they are stored with the tops on, unwashed, and in plasticlined bins. Topping and handling during washing increases cracking and scuffing damage, which leads to increased rot. Unwashed storage has worked successfully with harvests from light, sandy soils. Soil type, harvest conditions, and local experience should prevail in handling and storage decisions.

Ideal storage conditions for carrots are $32^{\circ} \mathrm{F}\left(0^{\circ} \mathrm{F}\right)$ at 99 percent relative humidity $(\mathrm{RH})$. Under these conditions, carrots have been stored successfully for more than 7 months with minimal losses (10 to 15 percent) due to dehydration and decay. At $33.8^{\circ} \mathrm{F}\left(1^{\circ} \mathrm{C}\right)$ and 98 percent $\mathrm{RH}$, the conditions common in most storage, the maximum recommended storage is 5 months.

Carrots for the cut and peel market are generally cut into 21-inch (5-cm) segments ("slugs"). These carrots may be held in plastic-lined bins prior to peeling and shaping and should have adequate air circulation and uniform temperature during storage to minimize decay and sprouting. Bunched carrots and forcing-type cut and peel carrots are highly perishable, especially with tops intact. They must be thoroughly precooled to $32^{\circ} \mathrm{F}\left(0^{\circ} \mathrm{C}\right)$ and can be stored at this temperature at 99 percent $\mathrm{RH}$ for up to 2 weeks. Top icing, although not necessary with properly precooled carrots, is often used for bunched carrots to demonstrate that low temperature and high humidity existed during transit.

During storage and transportation, carrots should not be exposed to ethylene gas from propane-powered lift trucks or produce such as apples or pears. Ethylene induces the production of compounds that cause bitterness in carrots.

\section{Postharvest Disorders}

The most important storage decays of carrots are gray mold (Botrytis spp.), watery soft rot (Sclerotinia spp.), Rhizopus rot, bacterial soft rot (Erwinia spp.), and sour rot (Geothrichurn spp.). Decay can be controlled by proper storage and handling to prevent mechani- 
cal injury (fluctuations in temperature during storage promotes water condensation and decay). Whiteness of the cut or peeled surface ("white blush"), common on fresh-cut carrots (cut and peel, sticks, and coins), is caused by dehydration. Use sharp cutting blades and keep free moisture on work surfaces during packaging to prevent this disorder. A white, edible coating that reduces white blush has been developed that may be applied before packaging.

\section{Shipping Containers}

Shipping containers for the various types of processed carrots are as follows.

\section{Topped}

- 50-pound carton or sack containing loose carrots or ten 5-pound film (cello) bags

- 40-pound carton of 1-pound cello bags

- 26-pound carton of bunched carrots

- 25-pound carton of loose carrots

- 24-pound carton of 1-pound cello bags

- 15-pound carton of twenty 12-ounce cello bags

\section{Bunched}

26-pound carton or crate

\section{Mini-carrots}

20-pound carton of 1-pound cello bags

15-pound carton of twenty 12-oz cello bags

\section{Fresh-cut}

18-pound carton of 1- or 2-pound cello bags

9-pound carton of 1-pound cello bags

\section{MARKETING}

Carrots are shipped from California year-round. Shipments are highest from December to August. California produces about 85 percent of all carrots grown in the United States. Colorado, Florida, Michigan, Texas, and Washington are other important carrot-producing states. Major carrot imports come from Canada and Mexico.

\section{FOR FURTHER INFORMATION}

To order or obtain ANR publications and other products, visit the ANR Communication Services online catalog at http:// anrcatalog.ucdavis.edu or phone 1-800-994-8849. You can also place orders by mail or FAX, or request a printed catalog of our products from

University of California

Agriculture and Natural Resources

Communication Services

6701 San Pablo Avenue, 2nd Floor

Oakland, California 94608-1239

Telephone 1-800-994-8849 or (510) 642-2431

FAX (510) 643-5470

E-mail: danrcs@ucdavis.edu

C 1997, 2008 The Regents of the University of California Division of Agriculture and Natural Resources

All rights reserved.

No part of this publication may be reproduced, stored in a retrieval system, or transmitted, in any form or by any means, electronic, mechanical, photocopying, recording, or otherwise, without the written permission of the publisher and the authors.

Publication 7226

ISBN-13: 978-1-60107-616-8

The University of California prohibits discrimination or harassment of any person on the basis of race, color, national origin, religion, sex, gender identity, pregnancy (including childbirth, and medical conditions related to pregnancy or childbirth), physical or mental disability, medical condition (cancer-related or genetic characteristics), ancestry, marital status, age, sexual orientation, citizenship, or service in the uniformed services (as defined by the Uniformed Services Employment and Reemployment Rights Act of 1994: service in the uniformed services includes membership, application for membership, performance of service, application for service, or obligation for service in the uniformed services) in any of its programs or activities.

University policy also prohibits reprisal or retaliation against any person in any of its programs or activities for making a complaint of discrimination or sexual harassment or for using or participating in the investigation or resolution process of any such complaint.

University policy is intended to be consistent with the provisions of applicable State and Federal laws.

Inquiries regarding the University's nondiscrimination policies may be directed to the Affirmative Action/Equal Opportunity Director, University of California, Agriculture and Natural Resources, 1111 Franklin Street, $6{ }^{\text {th }}$ Floor, Oakland, CA 94607, (510) 987-0096. For information about ordering this publication, telephone 1-800-994-8849. For assistance in downloading this publication, telephone 530-754-3927.

An electronic copy of this publication can be found at the ANR Communication Services catalog Web site, http:// anrcatalog.ucdavis.edu.

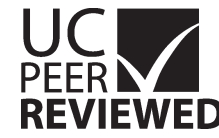

This publication has been anonymously peer reviewed for technical accuracy by University of California scientists and other qualified professionals. This review process was managed by the ANR Associate Editor for Vegetable Crops.

pr-11/08-SB/CR 